\title{
WOJCIECH ZOMERSKI
}

ORCID: 0000-0001-5740-723X

Uniwersytet Wrocławski

\section{O WPŁYWIE DOŚWIADCZEŃ REALNEGO SOCJALIZMU NA TEORIE DOGMATYKI PRAWA. W STRONĘ DEMOKRATYCZNEJ TEORII PRAWA?*}

\begin{abstract}
Abstrakt: Celem niniejszego artykułu jest ukazanie wpływu, jaki na rodzimą teorię dogmatyki prawa miało doświadczenie realnego socjalizmu. W tym celu najpierw pokrótce rekonstruuję krytykę dogmatyki w nurcie marksistowskim. Następnie omawiam dwie koncepcje dogmatyki prawa powstałe w tym okresie i zestawiam je z współczesną interpretacją dogmatyki prawa. Pokazuję, że obraz dogmatyki prawa w rodzimej refleksji teoretycznej jest paradoksalny, ale stabilny — dogmatyka jest postrzegana jako nauka podobna do nauk ścisłych, a jednocześnie akcentuje się jej daleko idącą autonomię względem tekstu prawnego oraz woli ustawodawcy. Jednocześnie zwracam uwagę na wewnętrzne napięcia $\mathrm{w}$ ramach przedmiotowych koncepcji, co ostatecznie prowadzi mnie do postawienia tezy, iż miały one charakter nie tyle opisowy czy normatywny, ile legitymizacyjny — były obliczone na ochronę autonomii dogmatyki i opracowywanego przez nie prawa. Staram się objaśnić ten fenomen, a następnie zwracam uwagę na ryzyka z tym związane i argumentuję, że obecnie aktualizuje się zapotrzebowanie na demokratyczną teorię prawa.
\end{abstract}

Słowa kluczowe: dogmatyka prawa, realny socjalizm, polska teoria prawa, naukowość, racjonalny ustawodawca

\section{WPROWADZENIE}

Czy dogmatyka prawa jest nauką? Pytanie to wyznaczało ramy dyskusji o dogmatyce w powojennej teorii prawa ${ }^{1}$. W niniejszym artykule chciałbym pokazać, że zarówno stawianie tego pytania, jak i treść udzielanych na nie odpowiedzi daje się

* Niniejsza publikacja zawiera skrótowe omówienie wybranych tez rozprawy doktorskiej pod tytułem Dogmatyka i edukacja prawnicza w post-analitycznej teorii prawa, napisanej na Wydziale Prawa, Administracji i Ekonomii Uniwersytetu Wrocławskiego pod kierownictwem prof. Adama Czarnoty oraz dr. Michała Stambulskiego, której obrona odbyła się w październiku 2020 roku.

${ }^{1}$ Dość powiedzieć, że szukanie odpowiedzi na to pytanie zajmowało takie tuzy polskiej teorii prawa, jak J. Wróblewski, Z. Ziembiński, K. Opałek, A. Peczenik, S. Ehrlich, A. Podgórecki czy L. Nowak. 
wytłumaczyć zewnętrznymi warunkami, w których formowała się powojenna teoria prawa. Rozumiem przez to, że stawianie w warunkach minionego ustroju tezy o naukowości dogmatyki było odpowiedzią na zakusy marksistowskiej formacji intelektualnej do podporządkowania prawa celom bieżącej polityki partyjnej. W tym sensie wpływ realnego socjalizmu na teorię dogmatyki prawa nie sprowadzał się do podporządkowania tej ostatniej do oczekiwań zastanego otoczenia społecznego, a przeciwnie - wiązał się z wyminięciem tych oczekiwań poprzez konstruowanie obrazów dogmatyki jako dziedziny autonomicznej względem otoczenia społecznego i władzy politycznej ${ }^{2}$. Wiele przy tym wskazuje, że wpływ, jaki miały autorytarne realia na teorię dogmatyki prawa, okazał się trwalszy aniżeli owe realia. W konkluzji zwracam uwagę na zagrożenia związane $\mathrm{z}$ tym stanem rzeczy, podnosząc, że to, co w warunkach realnego socjalizmu mogło skutecznie chronić autonomię prawa, w warunkach demokratycznych może jej zagrażać, to jest wiedzie do delegitymizacji prawa jako autonomicznej praktyki społecznej. To prowadzi mnie do zarysowania koncepcji demokratycznej teorii prawa, która czyniąc prawo responsywnym na przemiany w otoczeniu społecznym, miałaby za zadanie wzmacniać integralność wspólnoty politycznej.

\section{MARKSISTOWSKA KRYTYKA DOGMATYKI PRAWA}

Aby zdać sobie sprawę z kontekstu społecznego, w jakim kształtowała się rodzima teoria dogmatyki prawa, warto skrótowo zrekonstruować podstawowe zarzuty formułowane pod kątem dogmatyki w nurcie marksistowskim. Nurt marksistowski na gruncie prawoznawstwa rozwijał się w latach pięćdziesiątych za sprawą takich autorów, jak Stanisław Ehrlich ${ }^{3}$ czy wcześni Kazimierz Opałek oraz Jerzy Wróblew$\mathrm{ski}^{4}$. W nurcie tym zarzucano, że pod programową tezą o apolityczności dogmatyki skrywa się w istocie ,polityczna afirmatywność” burżuazyjnego prawa i państwa ${ }^{5}$. Podnoszono, że dogmatyka wypiera swoje oczywiste upolitycznienie, to jest fakt, że służy klasie posiadającej, a praktykujący ją prawnicy „są ściśle związani z aparatem przemocy klasowej”' $\mathrm{Z}$ tego powodu dogmatyka nie zasługuje na miano nauki — służy bowiem klasie, która w obliczu obiektywnych prawideł rozwoju życia

2 Por. J. Leszczyński, Pozytywizacja prawa w dyskursie dogmatycznym, Kraków 2010, s. 18.

3 Zob. S. Ehrlich, O metodzie formalno-dogmatycznej, „Państwo i Prawo” 1955, nr 3, s. 374 404; idem, Kilka uwag w sprawie metodologii nauk prawnych, „Państwo i Prawo” 1964, nr 11, s. 641-653.Więcej na ten krytyki dogmatyki prawa dokonanej przez Ehrlicha zob. W. Zomerski, Stanistaw Ehrlich's critique of legal dogmatics: Then and now, „Review of Central and East European Law" 45, 2020, nr 2, s. 314-333.

4 Zob. K. Opałek, J. Wróblewski, Pozytywizm prawniczy, „Państwo i Prawo” 1954, nr 1, s. 5-42.

5 Ibidem, s. 38.

6 Ibidem, s. 6. 
społecznego jest klasą schyłkową7. Nienaukowość dogmatyki wiąże się dodatkowo z tym, iż ograniczyła ona swój przedmiot badawczy wyłącznie do materiału normatywnego ${ }^{8}$. To z kolei uniemożliwia jej realizowanie zadań naukowych. Wszelkie nauki są bowiem naukami nomotetycznymi, to znaczy — zmierzają do odkrycia prawideł rządzących społeczną rzeczywistością. Dogmatyka natomiast takich prawideł nie identyfikuje, lecz ogranicza się do opisu, który jest przy tym niekompletny, jako że dotyczy tylko językowych przejawów prawa. Nauka prawa powinna być nie tyle nawet polityczna, ile partyjna - to bowiem partia komunistyczna, mając dostęp do praw obiektywnie rządzących rozwojem społecznym, reprezentuje interesy klasy robotniczej. Partyjna zaś postawa badacza musi się wiązać ze zdaniem sobie sprawy z tego, że „bez pogłębionego studium uchwał i dyrektyw partyjnych, które wiążą teoretyczno-polityczne założenia marksizmu z konkretnymi, praktycznymi zadaniami budownictwa socjalistycznego [...], nie ma mowy o przezwyciężeniu metody formalno-dogmatycznej"9.

\section{TEORIA PRAWA WOBEC MARKSISTOWSKIEJ FORMACJI INTELEKTUALNEJ}

To powiedziawszy, można domyślać się, że problem, który w latach powojennych próbowała rozwiązać marksistowska teoria prawa, dotyczył funkcjonowania przedwojennych aktów prawnych w realiach nowej formacji polityczno-społecznej. Powojenni prawnicy, zasłaniając się formalizmem, interpretowali przedwojenne akty prawne w sposób nieuwzględniający przemian otoczenia społeczno-politycznego, a zatem — z perspektywy dominującej formacji intelektualnej — służąc schyłkowej klasie posiadającej. Marksistowska teoria prawa w odpowiedzi na ten problem nie tylko postulowała upolitycznienie nauk prawnych, lecz utożsamiając klasę robotniczą z partią komunistyczną, opowiadała się także za ich upartyjnieniem, a więc podporządkowaniem prawa i jego nauki doraźnym celom partii komunistycznej ${ }^{10}$. Taka dynamika wygenerowała zapotrzebowanie na teorię dogmatyki prawa, która ochroniłaby jej autonomię ${ }^{11}$. Dostępnym sposobem obrony autonomii prawa było wykazanie, że prawo ma obiektywną treść, której poznanie jest możliwe dzięki nauce prawa. Rodzimi marksiści, opierając

7 S. Ehrlich, Kilka uwag..., s. 646; K. Opałek, J. Wróblewski, op. cit., s. 42.

8 S. Ehrlich, Kilka uwag..., s. 645.

9 S. Ehrlich, $O$ metodzie..., s. 386 n.

10 I to mimo przeciwnych zastrzeżeń jej autorów w tym względzie. Por. ibidem, s. 380-381, gdzie Ehrlich wskazuje, że „słusznej i nieodzownej krytyki błędnej i nienaukowej metody dogmatycznej nie należy rozumieć jako rezygnacji z badania norm”, albowiem zastąpienie „poważnej” analizy materiału normatywnego „czysto politycznymi” rozważaniami prowadziłoby do nihilizmu prawnego.

11 Por. M. Zirk-Sadowski, Prawo a uczestniczenie w kulturze, Łódź 1998, s. 41. 
się na nomologicznym modelu nauki, odmawiali jednak miana nauki wszystkim dziedzinom o charakterze idiograficznym. W rezultacie skuteczne wykazanie, że dogmatyka jest nauką, wymagało wpisania się w naturalistyczny klucz ${ }^{12}$. Tłumaczy to, dlaczego mimo otwartej niekompatybilności programów naturalistycznych i dogmatyki jako dyscypliny idiograficznej ${ }^{13} \mathrm{w}$ samym łonie rodzimej teorii prawa pojawiły się próby naturalistycznej interpretacji dogmatyki prawa. W dalszej części artykułu rekonstruuję trzy charakterystyczne cechy koncepcji dogmatyki prawa powstałych w tym okresie. Jak będę starał się wykazać, sposoby myślenia o dogmatyce wykształcone w opozycji do marksistowskiego paradygmatu okazały się trwalsze aniżeli ustrój realnego socjalizmu i do dziś wyznaczają dominujące w rodzimej refleksji teoretycznoprawnej sposoby myślenia o prawie i jego nauce.

\section{TEZA O PODOBIEŃSTWIE DOGMATYKI PRAWA DO NAUK ŚCISŁYCH}

Wzorcową próbę obrony dogmatyki prawa jako dziedziny naukowej stanowiła jej indukcjonistyczna interpretacja zaproponowana przez Aleksandra Peczeni$\mathrm{ka}^{14}$. W tej koncepcji przez dogmatykę rozumie się dziedzinę, której ostatecznym rezultatem działalności jest zespół twierdzeń o treści prawa obowiązującego oraz ukształtowanie się specyficznej terminologii prawniczej ${ }^{15}$. W celu wykazania, że tak rozumiana dogmatyka odpowiada indukcjonistycznemu modelowi nauk, Peczenik przyporządkowuje jej tezy teorii nauk ,wzorcowych”, to jest nauk przyrodniczych. Podstawowe podobieństwo między dogmatyką a wzorcowymi naukami przyrodniczymi polega na tym, że również ta pierwsza uzgadnia swoje twierdzenia z wynikami doświadczenia. Rolę danych doświadczenia dla dogmatyki odgrywają obowiązujące przepisy prawa stanowionego i inne wypowiedzi obowiązujące prawnie. Twierdzenia na podstawie owych danych nie są budowane dowolnie, a na podstawie licznych dyrektyw wykładni. Owe dyrektywy ograniczają swobodę interpretacyjną interpretatora w myśl zasady ścisłego przestrzegania prawa. Jeśli zaś nauka prawa wykracza poza tekst prawny i jego logiczne konsekwencje, to nie różni się zasadniczo w tym względzie od innych nauk, które także wychodzą poza swój materiał badawczy, opierając się na rozumowaniu indukcyjnym ${ }^{16}$.

12 Por. J. Leszczyński, op. cit., s. 55.

13 Tak Z. Pulka, Struktura poznania filozoficznego w prawoznawstwie, Wrocław 2004, s. 14 n.; oraz L. Morawski, Główne problemy wspótczesnej filozofii prawa. Prawo w toku przemian, Warszawa 2000, s. 297.

14 A. Peczenik, Wartość naukowa dogmatyki prawa, „Zeszyty Naukowe Uniwersytetu Jagiellońskiego” 132, „Prace Prawnicze” 26, 1966.

${ }^{15} \mathrm{Z}$ zastrzeżeniem, że ze względu na normatywny charakter prawa w wypadku nauk prawnych indukcja klasyfikująca i indukcja uogólniająca zostają zastąpione ich normatywnymi odpowiednikami. Zob. ibidem, s. 6.

16 Ibidem, s. 43. 
Leszek Nowak w celu wykazania naukowości dogmatyki posługuje się z kolei metodą idealizacji i konkretyzacji ${ }^{17}$. O naukowości dziedziny, podnosi poznański teoretyk prawa, przesądza nie fakt formułowania przez nią praw ogólnych w swojej strukturze powierzchniowej, a przyjmowanie owych praw w strukturze głębokiej ${ }^{18}$. Tak przeformułowane kryterium naukowości pozwala wykazać, że dogmatyka wykazuje podobieństwo do wysoko rozwiniętych nauk empirycznych, albowiem zawiera w swojej strukturze głębokiej całą teorię o charakterze praw ogólnych. Podstawowym prawem idealizacyjnym milcząco przyjmowanym w ramach dogmatyki jest zasada racjonalności, zakładająca, że wiedza i preferencje prawodawcy spełniają określone cechy (niesprzeczność, systemowość — jeśli chodzi o wiedzę, asymetryczność i przechodniość — jeśli chodzi o preferencje), a prawodawca wybiera spośród możliwych do podjęcia czynności te, które - z punktu widzenia tej wiedzy i tych preferencji — prowadzą do stanów rzeczy najbardziej pożądanych ${ }^{19}$. Prawnicy nie poprzestają jednak na przypisaniu wiedzy i preferencjom ustawodawcy właściwości formalnych, ale przyjmują również założenia o ich właściwościach materialnych, a konkretnie uznają, że prawodawca ten jest doskonały pod względem posiadanej: kompetencji językowej, wiedzy prawniczej, wiedzy empirycznej i aksjologii ${ }^{20}$. Założenia o racjonalności i doskonałości prawodawcy składają się na typ idealnego doskonałego prawodawcy, który tworzy kompleksową teorię idealizacyjną przyjmowaną w strukturze głębokiej dogmatyki prawa.

Zdaje się, że wyznaczony przez Peczenika oraz Nowaka sposób myślenia o dogmatyce jako dziedzinie przypominającej nauki przyrodnicze trwale ukształtował wyobrażenia teorii prawa na jej temat. Współczesny teoretyk prawa, Artur Kozak, obierając za swój cel obronę analitycznej teorii prawa z pozycji postanalitycznych, stwierdza, że rozumowania prawnicze przypominają rozumowania matematyczne, i podnosi, że prawo, niczym logikę, cechuje „bezwzględność przymiaru" - zastosowanie metod prawniczych przez dowolną osobę zawsze prowadzi do tej samej konkluzji ${ }^{21}$. Tym, co pozwala prawu na osiągnięcie owej matematycznej precyzji, są kulturowe konwencje wiążące prawników, które są silne niczym prawa przyrody ${ }^{22}$. Można zatem argumentować, że mimo otwarcie antynaturalistycznej postawy i nowatorskości poglądów Artura Kozaka z praktycznego punktu widzenia juryscentryczna wizja nauki prawa niesie z sobą te same konsekwencje co jej naturalistyczne poprzedniczki — oto dogmatycy dysponują metodą, która na kształt metody matematycznej pozwala dochodzić do intersubiektywnie weryfikowalnych rezultatów.

17 L. Nowak, Interpretacja prawnicza. Studium z metodologii prawoznawstwa, Warszawa 1973, s. 16 n.

18 Ibidem, s. 12.

19 Ibidem, s. 25.

20 Ibidem, s. 43-46.

21 Por. A. Kozak, Myślenie analityczne w nance prawa i praktyce prawniczej, red. M. Pichlak, Wrocław 2010, s. 76.

22 Ibidem, s. 108. 


\section{AUTONOMIA WOBEC TEKSTU PRAWNEGO}

Pobieżne zapoznanie się z omówionymi właśnie koncepcjami mogłoby prowadzić do przekonania, że teza o naukowości dogmatyki sprowadza się do tezy o determinacji: dogmatyka jest związana materiałem normatywnym, a metoda prawnicza pozwala - bez względu na podmiotowe uposażenie interpretatora na jego intersubiektywne poznanie. Sami jednak autorzy dostarczają argumentów za tym, aby uznać, że jest to wyłącznie użyteczna fikcja, mająca na celu przykryć faktycznie praktyczny charakter działalności dogmatycznej.

Peczenik przyznaje wprost, że zasada ograniczenia materiałem normatywnych w przypadku nauk prawnych doznaje dużo dalej idących odstępstw, aniżeli ma to miejsce w wypadku nauk przyrodniczych ${ }^{23}$. Nawet bowiem gdy prawnik tylko poznaje i logicznie opracowuje prawo, nierzadko - ze względu na konkurencyjny postulat niesprzeczności systemu prawa — zmuszony jest odstępować od niebudzącego wątpliwości tekstu. O ile bowiem fakty będące podstawą do uogólniania $\mathrm{w}$ dziedzinie zdań nie mogą być $\mathrm{z}$ sobą sprzeczne, o tyle konkretne przepisy ustanowione przez ustawodawcę już tak. To odróżnia dogmatykę od nauk przyrodniczych, albowiem przyrodnik nie idzie na żadne kompromisy z danymi doświadczenia, jest im bezwzględnie wierny ${ }^{24}$.

Kolejną cechą, która zdaniem autora wyraźnie odróżnia nauki prawne od nauk przyrodniczych, jest „subiektywność uogólnień” — o ile prawidłowe uzgodnienie faktów w dziedzinie zdań prowadzi najczęściej do tożsamych uogólnień, o tyle uogólnienie norm może prowadzić do odmiennych rezultatów ${ }^{25}$. Tym samym Peczenik mimowolnie przyznaje, że jego koncepcja ma charakter użytecznej fikcji. Staje się to natomiast zupełnie ewidentne, kiedy autor przyznaje, że reguły egzegezy są tylko „pozornie precyzyjne”, a sędzia wprawdzie czuje się związany prawem, ale de facto dysponuje w swojej działalności dużą dozą wolności ${ }^{26}$. Na pytanie, czy w takim razie zamiast kultywować złudzenie zupełnie obiektywnej i całkowicie zdeterminowanej interpretacji nie lepiej uświadomić sędziemu jego swobodę i zalecać mu trzymanie się wartościowań w społeczeństwie popularnych, Peczenik udziela odpowiedzi negatywnej, wskazując, że taka „szczerość” byłaby bardzo niebezpieczna, albowiem mogłaby wywołać u sędziego przekonanie o zupełnej dowolności w procesie interpretacji ${ }^{27}$.

Podobnie mają się sprawy z idealizacyjną koncepcją dogmatyki Nowaka. Przyjęcie tezy o podobieństwie nauk prawnych do nauk ścisłych nie przeszkadza bowiem poznańskiemu teoretykowi prawa jednocześnie akcentować, że twierdzenia dogmatyczne nie mają charakteru opisu prawa, a są podanymi w formie opiso-

\footnotetext{
23 A. Peczenik, op. cit., s. 100.

24 Ibidem.

25 Ibidem, s. 104.

26 Ibidem, s. 112-113.

27 Ibidem.
} 
wej projektami jego usprawnienia ${ }^{28}$. Interpretator może uznać, że dany przepis jest wadliwie zredagowany, ale skoro już zajmuje się jego wykładnią, to musi wskazać, jak należy go „właściwie” zinterpretować — podać taki sposób wykładni tego przepisu, który prowadziłby do sformułowania operatywnej normy. A to znaczy, że musi założyć, choćby tak nie było, że ten, od kogo ów przepis pochodzi, jest prawodawcą wewnętrznie doskonałym. Bez tego założenia prawo i prawnicy nie mogliby spełniać swojej społecznej funkcji ${ }^{29}$. Autor omawianej koncepcji nie poczytuje jednak tej odmienności za okoliczność podważającą tezę o jedności nauk. Jak tłumaczy, dogmatyka jest nauką praktyczną, której jedyna osobliwość polega na tym, że swoje pozapoznawcze cele osiąga, przyjmując dogmatycznie (bo bez kontroli empirycznej) założenia o doskonałości wewnętrznej prawodawcy. Na potencjalny zarzut, który wskazywałby, że świadczy to o nieprzystawalności empirycznego modelu nauki do dogmatyki, Nowak odpowiada: tezy prawoznawstwa nie są niesprawdzalne, lecz jedynie niesprawdzane, albowiem do osiągnięcia celu, jaki sobie prawnicy stawiają (optymalizacja prawa), ich empiryczna weryfikacja nie jest potrzebna ${ }^{30}$. Taki wniosek prowadzi Nowaka nie tyle do wycofania się z swoich wyjściowych hipotez, ile do ich modyfikacji ${ }^{31}$, to jest uznania, że dogmatyka prawa zasadniczo odpowiada empirycznemu modelowi nauk ${ }^{32}$.

Również Kozak zdaje się zdradzać, że jego koncepcja wraz z założeniem istnienia metody prawniczej na wzór metody matematycznej ma charakter pewnej użytecznej fikcji. Wrocławski filozof prawa, z jednej strony, z całą stanowczością stwierdza bowiem, że prawnicy dysponują metodą na kształt tej znanej matematykom, a z drugiej stwierdza, że kształcenie prawnicze przypomina raczej trening aniżeli edukację w ścisłym tego słowa znaczeniu ${ }^{33}$, co rozwija, posługując się metaforami „trybiku w maszynie” oraz ,przesłoniętego algorytmu”" ${ }^{4}$. Mając zaś na uwadze, że pojęcie treningu zwykło się odnosić do materii, której nie da się — w przeciwieństwie do matematyki — „objąć umysłem”, a której należy się niejako wyuczyć przez wykształcenie mechanicznych, cielesnych nawyków, przypominających warunkowanie Pawłowa, trudno nie upatrywać w takim postawieniu sprawy wyraźnej sprzeczności.

\section{AUTONOMIA WOBEC RZECZYWISTEGO USTAWODAWCY}

Przedstawiony obraz dopełnia programowy antyintencjonalizm rodzimej teorii dogmatyki prawa. Peczenik, rozważając adekwatność konkurencyjnych teorii wy-

${ }^{28}$ L. Nowak, op. cit., s. 173 n.

29 Ibidem, s. 174.

30 Ibidem, s. 206.

31 Krytyczny wobec tego zabiegu pozostaje M. Zirk-Sadowski, op. cit., s. 81.

32 L. Nowak, op. cit., s. 101.

33 A. Kozak, op. cit., s. 218.

34 Zob. A. Kozak, Granice prawniczej władzy dyskrecjonalnej, Wrocław 2002, s. 44; Regionalizacja rozumu? Spotkanie prawa i filozofi, rozmowa Artura Kozaka z Leszkiem Kleszczem), red. P. Jabłoński, [w:] Perspektywy juryscentryzmu, red. P. Kaczmarek et al., Wrocław 2011, s. 36. 
kładni, podnosi, że zwolennicy wariantów obiektywistycznych orientują się „raczej” na tekst prawny aniżeli jakiekolwiek inne nieformalne materiały świadczące o woli normodawcy, podczas gdy zwolennicy ich subiektywnych odpowiedników kładą w większej mierze nacisk na rekonstrukcję woli normodawcy ${ }^{35}$. Obiektywne teorie wykładni, thumaczy autor, preferowane są tam, gdzie autorytet normodawcy i interpretatora wprawdzie się wzajemnie równoważą, ale interpretator z jakiegoś powodu jest niechętny normodawcy, a ich subiektywne odpowiedniki dominują tam, gdzie autorytet osoby ustanawiającej daną normę jest większy niż autorytet osoby ją interpretującej. Sam Peczenik nie opowiada się otwarcie za żadną z teorii wykładni. Mając jednak na uwadze przede wszystkim fakt, że autor charakteryzuje obiektywne wykładnie prawa jako niezainteresowane wolą ustawodawcy i oparte na maksymie „ustawa jest mądrzejsza od ustawodawcy”, a sam problemu woli ustawodawcy nie problematyzuje i redukuje go do postulatu poszanowania tekstu prawnego ${ }^{36}$, można przyjmować, iż indukcjonistyczna koncepcja dogmatyki opiera się na obiektywnej teorii wykładni, czyli — jak przyznaje sam Peczenik — teorii podszytej niechęcią interpretatora wobec normodawcy. Powodów niechęci dla normodawcy można się tylko domyślać, ale pewną wskazówkę może stanowić to, jak na teoretyczne poglądy Peczenika w tym względzie wpłynęła przeprowadzka w 1968 roku do Szwecji i późniejsze życie w warunkach liberalnej demokracji ${ }^{37}$.

Na poziomie teoretycznym intencjonalizm odrzuca także Nowak. Autor zaznacza, że psychologizm i intencjonalizm dogmatyki jest pozorny - występuje on jedynie w jej strukturze powierzchniowej, kiedy mowa jest o intencjach i zamiarze ustawodawcy ${ }^{38}$. Prawnicy, mimo używania tej terminologii, milcząco przyjmują założenie, że prawodawca, którego intencje ustalają, nie jest osobą psychofizyczną, a nawet grupą takich osób. Kiedy prawnik mówi o intencji ustawodawcy, nie ma bowiem na myśli realnego ustawodawcy, lecz typ idealny doskonałego prawodawcy. Należy przy tym powtórzyć, że koncepcja racjonalnego ustawodawcy nie zakłada, że ustawodawca je st racjonalny, lecz że prawnicy, interpretując prawo, zachowują się tak, jakby ustawodawca był racjonalny, bez względu na to, czy tak rzeczywiście jest. Prawo tworzone przez realnego ustawodawcę bywa bowiem nielogicznie i sprzeczne, a zadaniem prawnika, który w wyniku interpretacji przechodzi z poziomu przepisów prawnych na poziom norm prawnych, jest właśnie urzeczywistnienie założenia o racjonalności prawodawcy ${ }^{39}$.

35 A. Peczenik, op. cit., s. 109.

36 Por. treść przyjmowanych przez Peczenika dyrektyw (ibidem, s. 30-31), a także fragment (ibidem, s. 32), w którym autor redukuje problem zgodności wykładni z wolą ustawodawcy do problemu wierności tekstowi prawnemu.

37 Por. A. Peczenik, On Law and Reason, „Law and Philosophy Library” 8, 2009, s. 27-32, gdzie autor podnosi, iż „Decyzje prawne powinny być lojalne względem demokratycznie wybranych legislatur. Szwedzka doktryna źródeł prawa zaleca dlatego, by osoba interpretująca prawo zawsze brała pod uwagę instrukcję legislatorów zamieszczone w travaux preparatoires"; jeśli nie podano inaczej, przeł. W.Z.

38 L. Nowak, op. cit., s. 33-36.

39 Por. ibidem, s. 172. 
Intencjonalizm jest zasadniczo odrzucany również we współczesnej polskiej teorii prawa ${ }^{40}$. Kozak taką postawę thumaczy ,politycznym i ideologicznym minimalizmem" współczesnej władzy demokratycznej, który zasadza się na tym, że za większością jej działań nie stoi żaden plan ani pomysł na społeczną zmianę. „Zminimalizowana" władza nie ma na to czasu, bo pochłonięta jest walką o utrzymanie się przy władzy ${ }^{41}$. W tym ujęciu norma prawna to wypowiedź językowa, którą prawnicy muszą zrekonstruować z ,intelektualnych konwulsji ustawodawstwa zdeterminowanego przez politykę” i która tym samym porządkuje „chaos parlamentarnej polityki" ${ }^{2}$. Polityka może realnie oddziaływać na życie obywateli tylko dlatego, że jest ktoś, kto nie jest uwikłany w doraźne interesy koalicyjne, kto nie musi się przejmować długością kadencji, ktoś, czyje kryteria nie zależą od ulotnego poparcia elektoratu: „Ten ktoś układa i porządkuje wypowiedzi prawodawców produkowane na użytek chwili, i nadaje im logiczne konsekwencje całkowicie obok intencji realnych prawodawców"43.

\section{DOŚWIADCZENIE REALNEGO SOCJALIZMU A TEORIA DOGMATYKI PRAWA}

Przedstawiona analiza ujawnia pewien paradoks związany z zastanym obrazem dogmatyki prawa w rodzimej teorii prawa. $Z$ jednej strony poszczególni autorzy są niezwykle zdeterminowani w wykazaniu podobieństwa dogmatyki prawa do nauk ścisłych, a z drugiej zdają się mimowolnie przyznawać, że żadna intersubiektywna metoda poznania prawa nie istnieje, a założenie o jej istnieniu ma charakter fikcji. Trudno w związku z tym nie odnieść wrażenia, że celem poszczególnych autorów było nie tyle objaśnienie czy nawet normow anie działalności dogmatyki, ile jej legitymizacja ${ }^{44}$. Jeżeli zapytać o przyczyny takiego stanu rzeczy, należy zwrócić uwagę na szerszy kontekst formowania się rodzimej teorii dogmatyki prawa. W warunkach realnego socjalizmu ugruntowanie szeroko rozumianej praktyki prawniczej w mocnej tezie o naukowości miało zagwarantować prawu i opracowującym go prawnikom autonomię względem autorytarnej władzy politycznej. Tym samym kształt, jaki przybrały koncepcje dogmatyki z tego okresu, był podyktowany polityczną alienacją władzy i jednoczesnymi próbami podporządkowania owej władzy nauki prawa ${ }^{45}$.

40 A. Kozak, Granice prawniczej władzy..., s. 112-121; L. Morawski, Teoria prawodawcy racjonalnego a postmodernizm, „Państwo i Prawo” 2000, nr 11, s. 29-38; J. Leszczyński, op. cit., s. 193-194; M. Matczak, Imperium tekstu. Prawo jako postulowanie i urzeczywistnianie świata możliwego, Warszawa 2019, s. 41-120.

41 Por. A. Kozak, Myślenie analityczne..., s. 118.

42 Ibidem, s. 209.

43 Ibidem.

${ }^{44}$ Por. ibidem, s. 110, gdzie autor wprost jako swój cel, ale i cel filozofii prawa jako takiej, identyfikuje legitymizację prawa.

45 Podobnie J. Leszczyński, op. cit., s. 55. 
W tym duchu daje się zwłaszcza wytłumaczyć „kariera”, jaką w dyskursie najpierw teoretycznym, a potem praktycznym zrobiła figura racjonalnego ustawodawcy ${ }^{46}$. Figura ta, jako element prawniczego dyskursu interpretacyjnego, z jednej strony gwarantuje daleko idącą autonomię prawników względem ustawodawcy i jego wytworów, a $\mathrm{z}$ drugiej pozwala ukryć ten fakt pod pozorem lojalności prawników wobec prawodawcy. Wyposażenie prawników w narzędzie służące korygowaniu „błędów” legislatora bez konieczności jego otwartej krytyki staje się w ten sposób wyrazem snu ,urzędnika o władzy, która nigdy się nie myli, a jeśli nawet myli się, to jego zadaniem jest wykazanie, że jednak się nie myli" ${ }^{\prime 7}$. Jak thumaczy bowiem Lech Morawski, nie ma przypadku, w którym figura ta rozprzestrzeniła się w prawniczym dyskursie praktycznym w czasach realnego socjalizmu, gdzie „oficjalnie obowiązywał dość niewolniczy styl interpretacji przepisów prawa, który zasadniczo nie tolerował żadnej otwartej krytyki prawodawców"48. Do podobnych wniosków dochodzi Ewa Łętowska, która wprawdzie nie problematyzuje zagadnienia woli ustawodawcy, ale trafnie odnotowuje, że powoływanie się na wolę ustawodawcy stało się w dyskursie praktycznym swoistą „,czapką niewidką”, kamuflażem zabiegów interpretacyjnych, będącą wyrazem hipokryzji prawników. Tę hipokryzję autorka — podobnie jak Morawski — thumaczy dziedzictwem czasów realnego socjalizmu, w których prawo postrzegano jako urzeczywistnienie woli klasy panującej i negowano konieczność jego interpretacji ${ }^{49}$.

Można zatem mówić o dialektycznym oddziaływaniu między otoczeniem społecznym a teorią prawa. Marksistowska krytyka dogmatyki, wychodząc naprzeciw politycznemu zapotrzebowaniu ${ }^{50}$, „zmusiła” analitycznych teoretyków prawa - piszących w scjentystycznych warunkach realnego socjalizmu - do poszukiwania „twardych” naturalistycznych kryteriów naukowości prawa. Zarówno Peczenik, jak i Nowak doszli jednak do „niewygodnych” wniosków — dogmatyka tych kryteriów nie spełnia. Scjentystyczny klimat intelektualny skutkujący brakiem teoretycznej alternatywy, z jednej strony, oraz społeczne zapotrzebowanie

${ }^{46} \mathrm{Na}$ temat przenikania koncepcji figury racjonalnego prawodawcy do praktyki prawniczej oraz potocznej wiedzy o prawie zob. S. Wojtczak, Wplyw konceptu „racjonalnego prawodawcy”, na polska kulturę prawna, [w:] Wielowymiarowość prawa, red. J. Czapska, M. Dudek, M. Stępień, Toruń 2014, s. 87-104.

47 L. Morawski, Teoria prawodawcy..., s. 35.

48 Ibidem.

49 Por. E. Łętowska, Boska szuka interpretacji, [w:] Prawo, społeczeństwo, jednostka. Księa jubileuszowa dedykowana Profesorowi Leszkowi Kubickiemu, red. A. Łopatka, B. Kunicka-Michalska, S. Kiewlicz, Warszawa 2003, s. 26.

50 Por. S. Ehrlich, O metodzie..., s. 374: „Postawienie zagadnienia przezwyciężenia metody formalno-dogmatycznej jako tematu dyskusji w Komitecie Nauk Prawnych PAN oznacza jednocześnie wysunięcie postulatu stosowania metody dialektyki materialistycznej w naszych pracach badawczych”. W tym samym numerze „Państwa i Prawa” zob. też wytyczne III Plenum KC PZPR bezpośrednio poprzedzające artykuł Ehrlicha: Redakcja „Państwa i Prawa”, Niektóre zagadnienia polityczno-prawne w świetle III Plenum KC PZPR, „Państwo i Prawo” 1955, nr 3, s. 361-373. 
na osadzenie prawa na mocnym fundamencie ontologicznym, z drugiej, przesądziły jednak o tym, że wspomniani autorzy dowodzili czegoś wprost przeciwnego. $\mathrm{Z}$ tego powodu próby obrony dogmatyki jako nauki nie polegały na zakwestionowaniu prawomocności naturalistycznego modelu nauk, lecz sprowadzały się do wykazania, że dogmatyka temu modelowi odpowiada.

Nieufność wobec polityczności, a także fakt jej maskowania w okresie realnego socjalizmu daje się wytłumaczyć i uzasadnić. Przekucie tej nieufności w konkretne rozwiązania teoretyczne i praktyczne było najprawdopodobniej warunkiem koniecznym zaistnienia quasi-autonomicznego dyskursu prawnego, to jest namiastki praworządności możliwej do osiągnięcia w systemie autorytarnym. To, co jednak problematyczne, to fakt, że owa zawoalowana wrogość teorii prawa względem polityczności, usprawiedliwiona niedemokratycznymi realiami, okazała się trwalsza aniżeli niedemokratyczny ustrój realnego socjalizmu. Ilustrację w tym względzie stanowi juryscentryczna wizja nauki prawa, która afirmując figurę racjonalnego ustawodawcy jako składową dyskursu prawniczego, akcentuje w jeszcze mocniejszy sposób wątki, których u „twórcy” jego teoretycznego pierwowzoru można było się tylko domyślać.

Nowak tylko raz w sposób otwarty zdradza się bowiem z negatywnym stosunkiem do władzy politycznej wymowną metaforą, w której porównuje ustawodawcę do obłąkanego króla, którego „bredzenia” z punktu widzenia prawników rekonstruujących wiedzę i oceny przypisywane prawodawcy są „tym lepsze, im mniej jasne i mniej liczne" 51 . To, co zasadniczo skrywane czy też wyparte u Nowaka, u autora Granic prawniczej władzy dyskrecjonalnej wysuwa się na główny plan $^{52}$. Kozak nie kryje się bowiem ze swoim negatywnym stosunkiem do demokratycznej władzy. Samego demokratycznego ustawodawcę pochłoniętego walką o władzę porównuje zaś - w podobnym duchu jak Nowak — do pływaka, od którego „trudno oczekiwać [...], że będzie płynął $\mathrm{w}$ jakim zaplanowanym kierun$\mathrm{ku}$, gdy ma on poważne kłopoty z utrzymaniem się na powierzchni wody"53, co ostatecznie ma uzasadniać całkowite ignorowanie jego woli.

Na tym podobieństwa między koncepcją Nowaka a Kozaka się nie kończą. Jeżeli bowiem za główną funkcję scjentyzmu uznać umożliwienie pewnej fikcji, zgodnie z którą działający mogą być autonomiczni wobec tradycji i własnego doświadczenia ${ }^{54}$, to należy przyjąć, że juryscentryzm zdołał obronić rdzeń scjentystycznej tezy. Wrocławski teoretyk prawa, akceptując tezę o niemożliwości niezapośredniczonego poznania, nie opowiada się bowiem za czynną rolą podmiotu poznania, a „stapia” podmiot i przedmiot poznania w jedno. Prawnik nie jest w stanie wprawdzie pozostawać autonomicznym względem tradycji (albowiem przez prawnika przemawia właśnie tylko tradycja powstała wokół interpretacji

${ }^{51}$ Zob. L. Nowak, op. cit., s. 176.

52 Por. A. Kozak, Granice prawniczej władzy..., s. 7.

53 Ibidem, s. 175.

54 Por. J. Leszczyński, op. cit., s. 54; M. Zirk-Sadowski, op. cit., s. 11-12. 
tekstów prawnych), ale jak najbardziej może i powinien być autonomiczny względem własnych jednostkowych doświadczeń. Kozak dochodzi zatem do wniosku, że możliwe jest budowanie intersubiektywnych twierdzeń na temat prawa, lecz ich zasięg jest zrelatywizowany do określonej kultury prawnej, czym zdaje się wtórować swojemu poprzednikowi - metodologicznemu naturaliście Nowakowi ${ }^{55}$.

Podobieństwo nie dotyczy przy tym jedynie praktycznych konsekwencji przyjęcia tych teorii, ale też szerszego kontekstu ich powstania. O ile koncepcja Nowaka (i Peczenika) była odpowiedzią na marksistowską krytykę tradycyjnych ujęć prawa $\mathrm{z}$ jednej strony, a $\mathrm{z}$ drugiej na praktykę polityczną PRL, o tyle juryscentryzm $z$ jednej strony stanowi reakcję na postmodernizm, a $z$ drugiej zdaje się reakcją na spór między światem prawa a polityki rozgorzały w czasie pierwszych rządów Prawa i Sprawiedliwości (lata 2005-2007) ${ }^{56}$. Pośrednio przyznaje to sam autor $^{57}$. Dodać przy tym można, że wszystkie cytaty świadczące o nieufności Kozaka wobec demokracji pochodzą z Myślenia analitycznego w nauce prawa i praktyce prawniczej, a zatem pracy, która powstawała w latach bezpośrednio poprzedzających przedwczesną śmierć autora (22 lutego 2009 roku), a nie sposób znaleźć podobnych wypowiedzi w Granicach prawniczej władzy dyskrecjonalnej z roku 2002.

\section{W STRONĘ DEMOKRATYCZNEJ TEORII PRAWA?}

To powiedziawszy, wydaje się, że programowa nieufność polskiej teorii prawa względem polityczności, wyniesiona z niedemokratycznego ustroju, współcześnie - przy założeniu o jej oddziaływaniu na samoświadomość dogmatyki i jej praktykę - może generować problematyczne napięcie między prawem a polityką. Dzieje się tak, ponieważ projekt ugruntowania szeroko rozumianej praktyki prawniczej w mocnej tezie o naukowości w jakiejś mierze petryfikuje tę praktykę, czyniąc ją przewidywalną i stabilną, ale nie służy jej zewnętrznej akceptacji ${ }^{58}$. Wyparcie tematyki polityczności może przy tym prowadzić do jurydyzacji polityki. Ta jurydyzacja wiąże się, po pierwsze, z założeniem, że wola polityczna, aby wywołać skutki, musi przyjąć z góry określoną formę, a po drugie, że dogmatyka

55 Por. L. Nowak, op. cit., s. 205.

56 Oczywiście analogia ta ma wyraźne ograniczenia, których omówienie wykracza poza ramy niniejszego opracowania.

57 Nuta polemiczna z rządami Prawa i Sprawiedliwości wybrzmiewa między innymi w dyskusji z 2008 roku, podczas której autor stwierdził, że „,prawo dawno sobie dało spokój z sprawiedliwością”, a na reakcję uczestniczki dyskusji („A Prawo i Sprawiedliwość?”) odpowiedział, że „to jest czysto polityczna zbitka, która nie ma nic wspólnego z realiami" — Regionalizacja rozumu?, s. 44-45. Można przy tym dodać, że podobną interpretację juryscentryzmu wysuwa uczeń profesora Kozaka; zob. M. Pichlak, Aporie teorii, paradoksy praktyki. O wewnętrznych napięciach w obrębie juryscentryzmu, [w:] Profesjonalna kultura prawnicza, red. M. Pichlak, Warszawa 2012, s. 59-74.

58 Por. uwagi A. Bator, Wstęp, [w:] A. Kozak, Myślenie analityczne..., s. 14. 
istnieje dzięki kontrastowi między racjonalną analizą prawniczą a nieracjonalną rywalizacją polityczną $a^{59}$, co w rodzimym prawoznawstwie doskonale ilustruje odróżnianie przepisu (to jest niedoskonałego dzieła realnego ustawodawcy) od normy (czyli doskonałego dzieła prawnika) czy też języka tworzenia prawa (języka prawnego) od języka jego stosowania (języka prawniczego). Jurydyzacja pola politycznego oznacza, że polityczność nie ma innych kanałów oddziaływania na prawo aniżeli przyjęcie nowej legislacji, co jednak — ze względu na daleko idącą autonomię prawników - nie gwarantuje, że prawodawca osiągnie zamierzony cel $^{60}$. Każda interwencja polityczna jest postrzegana przez prawników jako zewnętrzna przemoc. Jak wskazuje — za Chantal Mouffe — Michał Stambulski, wyparcie polityczności nie powoduje jednak jej zaniku ${ }^{61}$. Powraca ona w postaci populizmu, który przyglądając się prawu i polityczności z perspektywy realistycznej, uznaje polityczność za najważniejszy aspekt prawa. Populizm tym samym odrzuca twierdzenie o apolitycznym charakterze prawa i postuluje jego otwarte upolitycznienie. W tym sensie absolutyzowanie autonomii prawa względem otoczenia społecznego w dłuższym okresie może prowadzić do skutku odwrotnego od zamierzonego, to jest wulgarnej polityzacji prawa.

W mojej ocenie, mając na uwadze, że współcześnie prawo legitymizowane jest przez czynnik polityczny, czyli demokratyczny kontekst jego powstawania, słuszny wydaje się zwrot ku czemuś, co proponuję nazwać demokratyczną teorią pra$w^{62}$. Przez demokratyczną teorię prawa rozumiem taką teorię prawa, która za swój cel obiera uczynienie prawa zdolnym do odpowiedzialnej, krytycznej i wybiórczej adaptacji względem otoczenia społecznego zgodnie z ideałem responsywnego pra$w^{63}$. W tym sensie demokratyczna teoria prawa służyłaby integralności politycznej wspólnoty i miałaby za zadanie rozładować napięcie między prawem a polityką. Choć niewątpliwie koncepcja demokratycznej teorii prawa wymaga dalszego objaśnienia oraz konkretyzacji, to już teraz można zasygnalizować, że wiązałaby się ona z przesunięciem akcentu w dyskursie dogmatycznym z eksperckości na szersze uczestniczenie w dialogu społecznym. W warunkach demokratycznych nie ma bowiem powodów, by prawnicy i prawo mieli dystansować się od otoczenia społeczne-

59 M. Stambulski, Polityczność w polskiej analitycznej teorii prawa. Zarys problematyki, „Archiwum Filozofii Prawa i Filozofii Społecznej” 2018, nr 3 (18), s. 68 n.

60 Por. A. Kozak, Granice prawniczej władzy..., s. 159-160, który tłumaczy, że pracodawca tworzący prawo, aby osiągnąć zakładane cele, musi wpisać się w prawniczy kod, którym posługują się prawnicy.

61 Por. M. Stambulski, op. cit., s. 68.

62 Por. J. Waldron, Can there be a democratic jurisprudence?, „New York University School of Law, Public Law and Legal Theory Research Paper Series”, praca nr 08-35, 2008.

63 Por. P. Nonet, P. Selznick, Law and Society in Transition. Toward Responsive Law, New Brunswick-London 2007, s. 76-77, którzy wskazują, że odpowiedzią na bolączki modelu autonomicznego, powstałego w odpowiedzi na model represyjny, zbytnio absolutyzujący autonomię prawa od otoczenia społecznego, jest model responsywny, charakteryzujący się zdolnością do odpowiedzialnej, krytycznej i wybiórczej adaptacji względem otoczenia społecznego. 
go. Przeciwnie, demokracja zasługuje na potraktowanie jej ,poważnie”, a zatem nie tylko jako wynik głosowania czy formalny ustrój, lecz pewien ideał życia społecznego. Nierzadko przeoczanym wkładem Kelsenowskiej koncepcji normy podstawowej w rozwój nauki o prawie jest spostrzeżenie, iż legitymizacja porządku prawnego ma zawsze charakter pozaprawny. Skoro zatem prawo przestało być wyobcowane, a jest tworzone w demokratycznym procesie legislacyjnym, i jako takie cieszy się demokratyczną legitymacją, to dogmatyka prawa powinna zacząć brać udział w społecznym dyskursie i podporządkować się logice demokratycznej, wychodząc naprzeciw wymaganiom co do legitymizacji przez perswazję i transparencję.

W warunkach demokratycznych prawo nie powinno być postrzegane jako niczyja własność, ale raczej jako miejsce nieustannego ścierania się rozmaitych perspektyw i interesów nieskończonej liczby aktorów społecznych. Prawo nie może być rozumiane jako własność prawników, albowiem w realiach demokratycznych jest ono stanowione przez ludzi dla ludzi i to im ostatecznie ma służyć. Prawo nie może być postrzegane również jako własność ustawodawcy, gdyż w warunkach demokratycznego państwa prawa służy ono między innymi ograniczaniu władzy. Aby jednak nie generowało to nadmiernego napięcia - jak ma to miejsce w tradycji myślenia o dogmatyce wyznaczonej przez Peczenika, Nowaka i Kozaka - autonomia ta nie może być absolutyzowana czy skrywana, lecz musi być egzekwowana w sposób transparentny i uzasadniony okolicznościami sprawy. Demokratyczny ustawodawca zasługuje na potraktowanie poważnie, to jest na każdorazowe wytłumaczenie, dlaczego w ocenie interpretatora odstąpienie od woli prawodawcy wyrażonej w tekście prawnym było konieczne. Tylko bowiem w ten sposób prawodawca będzie mógł wyeliminować swoje błędy i nauczyć się skuteczniej oddziaływać na życie obywateli, co z jego perspektywy, bez względu na przyjmowaną koncepcję prawa, jawi się jako podstawowy cel działalności prawodawczej. Otoczenie społeczne nie może być traktowane jako zagrożenie czy potencjalne źródło konfliktu, ale jako podmiot, względem którego w realiach demokratycznych prawnicy (w związku z praktycznym wymiarem ich działalności) muszą się wylegitymować, zamiast skrywać ów wymiar pod teoretycznymi konstruktami ukształtowanymi pod wpływem niedemokratycznych doświadczeń minionego ustroju.

Demokratyczna teoria prawa zwracałaby przy tym uwagę, że w warunkach praworządnej demokracji konflikt między prawem a władzą jest jeśli nie nieuchronny, to zawsze potencjalny. Pamiętając zaś, kto dysponuje w tym konflikcie realną siłą, osamotnieni prawnicy zdają się skazani na porażkę. Co w tej sytuacji mogą zrobić prawnicy? Po pierwsze, w warunkach pokoju z władzą polityczną mogą spojrzeć na demokratyczną władzę przychylniejszym okiem i zaakceptować jej roszczenia do sprawowania władzy, to jest podejmowania działań obliczonych na wywołanie określonej zmiany społecznej. Nie chodzi tu o subordynację prawa doraźnej polityce, a akceptację, że bez względu na przyjmowane rozstrzygnięcia teoretyczne, z perspektywy ustawodawcy i otoczenia społecznego prawo stanowi prawomocny instrument sprawowania władzy. Po drugie, prawnicy powinni ro- 
zejrzeć się za sojusznikiem, który w ewentualnym konflikcie z władzą polityczną pozwoli przechylić szalę zwycięstwa na korzyść tych pierwszych. Jedynym dostępnym sojusznikiem wydaje się społeczeństwo. Kiedy społeczeństwo w konflikcie prawo-władza polityczna opowie się za tym pierwszym? Wtedy, gdy będzie widzieć, że prawo odpowiada na zmieniające się potrzeby otoczenia społecznego i służy wielu grupom społecznym, nierzadko wbrew doraźnym interesom elit. Prawo bowiem, jak każda inna społecznie doniosła praktyka, jest tak autonomiczne, jak pozwala na to otoczenie społeczne. Nie musi to jednak oznaczać kapitulacji przed tym ostatnim. W dyskusji na temat tego, co jest prawem, ostatnie słowo należy do prawników, ale - jeżeli to stwierdzenie ma być faktem, a nie tylko naiwnym życzeniem — prawnicy w swojej działalności muszą w większej mierze niż dotychczas wchodzić w dialog z otoczeniem społecznym. Ceną za utrzymanie tezy o autonomii prawa względem władzy politycznej zdaje się zatem otwarcie prawa i prawników na otoczenie społeczne. Jakie mogłyby być praktyczne konsekwencje takiego zarysowania relacji prawa i polityczności? To już pytanie na osobny artykuł.

\title{
ON THE IMPACT OF REAL SOCIALISM ON THE THEORY OF LEGAL DOGMATICS: TOWARD A DEMOCRATIC THEORY OF LAW?
}

\author{
Summary
}

The aim of this paper is to demonstrate how the domestic theory of legal dogmatics has been affected by the experience of real socialism. To this end, in the first place the Marxist critique of legal dogmatics is reconstructed. Subsequently, three concepts of legal dogmatics are considered: two articulated originally in the response to this critique and one contemporary. It is argued that the image of legal dogmatics in domestic legal theory is paradoxical but stable: despite emphasizing the autonomy of legal dogmatics from legal texts as well as the intention of the legislator, it is argued that legal dogmatics resembles natural sciences. At the same time, attention is drawn to the internal tensions within the discussed concepts. This leads to the conclusion that the discussed concepts of legal dogmatics were neither descriptive nor prescriptive, but they had a solely legitimizing character: their underlying aim was to protect the autonomy of legal dogmatics and - co-construed by the latter - law. Finally, the explanation of this phenomena is provided and attention to dangers associated with it is drawn. In the conclusion, I argue that there is a growing need for a democratic theory of law.

Keywords: legal dogmatics, real socialism, Polish theory of law, scientificity, rational legislator

\section{BIBLIOGRAFIA}

Ehrlich S., Kilka uwag w sprawie metodologii nauk prawnych, „Państwo i Prawo” 1964, nr 11, s. $641-653$.

Ehrlich S., O metodzie formalno-dogmatycznej, „Państwo i Prawo” 1955, nr 3, s. 374-404.

Kozak A., Granice prawniczej władzy dyskrecjonalnej, Wrocław 2002. 
Kozak A., Myślenie analityczne w nauce prawa i praktyce prawniczej, red. M. Pichlak, Wrocław 2010.

Leszczyński J., Pozytywizacja prawa w dyskursie dogmatycznym, Kraków 2010.

Łętowska E., Boska szuka interpretacji, [w:] Prawo, społeczeństwo, jednostka. Księga jubileuszowa dedykowana Profesorowi Leszkowi Kubickiemu, red. A. Łopatka, B. Kunicka-Michalska, S. Kiewlicz, Warszawa 2003, s. 25-35.

Matczak M., Imperium tekstu. Prawo jako postulowanie i urzeczywistnianie świata możliwego, Warszawa 2019.

Morawski L., Główne problemy współczesnej filozofii prawa. Prawo w toku przemian, wyd. 2, Warszawa 2000.

Morawski L., Teoria prawodawcy racjonalnego a postmodernizm, „Państwo i Prawo” 2000, nr 11, s. $29-38$.

Nonet P., Selznick P., Law and Society in Transition. Toward Responsive Law, New Brunswick-London 2007.

Nowak K., Interpretacja prawnicza. Studium z metodologii prawoznawstwa, Warszawa 1973.

Opałek K., Wróblewski J., Pozytywizm prawniczy, „Państwo i Prawo” 1954, nr 1, s. 5-42.

Peczenik A., On Law and Reason, „Law and Philosophy Library” 8, 2009.

Peczenik A., Wartość naukowa dogmatyki prawa, „Zeszyty Naukowe Uniwersytetu Jagiellońskiego” 132, „Prace Prawnicze” 26, 1966.

Pichlak M., Aporie teorii, paradoksy praktyki. O wewnętrznych napięciach w obrębie juryscentryzmu, [w:] Profesjonalna kultura prawnicza, red. M. Pichlak, Warszawa 2012, s. 59-74.

Pulka Z., Struktura poznania filozoficznego w prawoznawstwie, Wrocław 2004.

Regionalizacja rozumu? Spotkanie prawa i filozofii, rozmowa Artura Kozaka z Leszkiem Kleszczem, red. P. Jabłoński, [w:] Perspektywy juryscentryzmu, red. P. Kaczmarek et al., Wrocław 2011, s. 23-53.

Redakcja „Państwa i Prawa”, Niektóre zagadnienia polityczno-prawne w świetle III Plenum KC PZPR, „Państwo i Prawo” 1955, nr 3, s. 361-373.

Stambulski M., Polityczność w polskiej analitycznej teorii prawa. Zarys problematyki, „Archiwum Filozofii Prawa i Filozofii Społecznej” 2018, nr 3 (18), s. 64-73.

Waldron J., Can there be a democratic jurisprudence?, „New York University School of Law, Public Law and Legal Theory Research Paper Series”, praca nr 08-35, 2008.

Wojtczak S., Wptyw konceptu ,racjonalnego prawodawcy” na polska kulture prawna, [w:] Wielowymiarowość prawa, red. J. Czapska, M. Dudek, M. Stępień, Toruń 2014, s. 87-104.

Zirk-Sadowski M., Prawo a uczestniczenie w kulturze, Łódź 1998.

Zomerski W., Stanistaw Ehrlich's critique of legal dogmatics: Then and now, „Review of Central and East European Law" 45, 2020, nr 2, s. 314-333. 